\title{
SAUDADES, GRANDE MESTRA LÍVIA DE OLIVEIRA
}

\author{
Hugo Leonardo MARANDOLA ${ }^{1}$
}

Cursei o mestrado no Programa de Pós-Graduação em Geografia da Unesp em Rio Claro entre 2015 e 2017. Tive o incomensurável privilégio de ser orientado por Lívia de Oliveira. Ao presidir minha banca de defesa da dissertação (MARANDOLA, 2017) ao lado das professoras Lúcia Helena Batista Gratão e Darlene Aparecida de Oliveira Ferreira, Lívia já havia completado 90 anos de idade. Essa foi a última banca presidida por Lívia (Foto 1).

Foto 1: A última banca presidida por Lívia de Oliveira, outubro de 2017

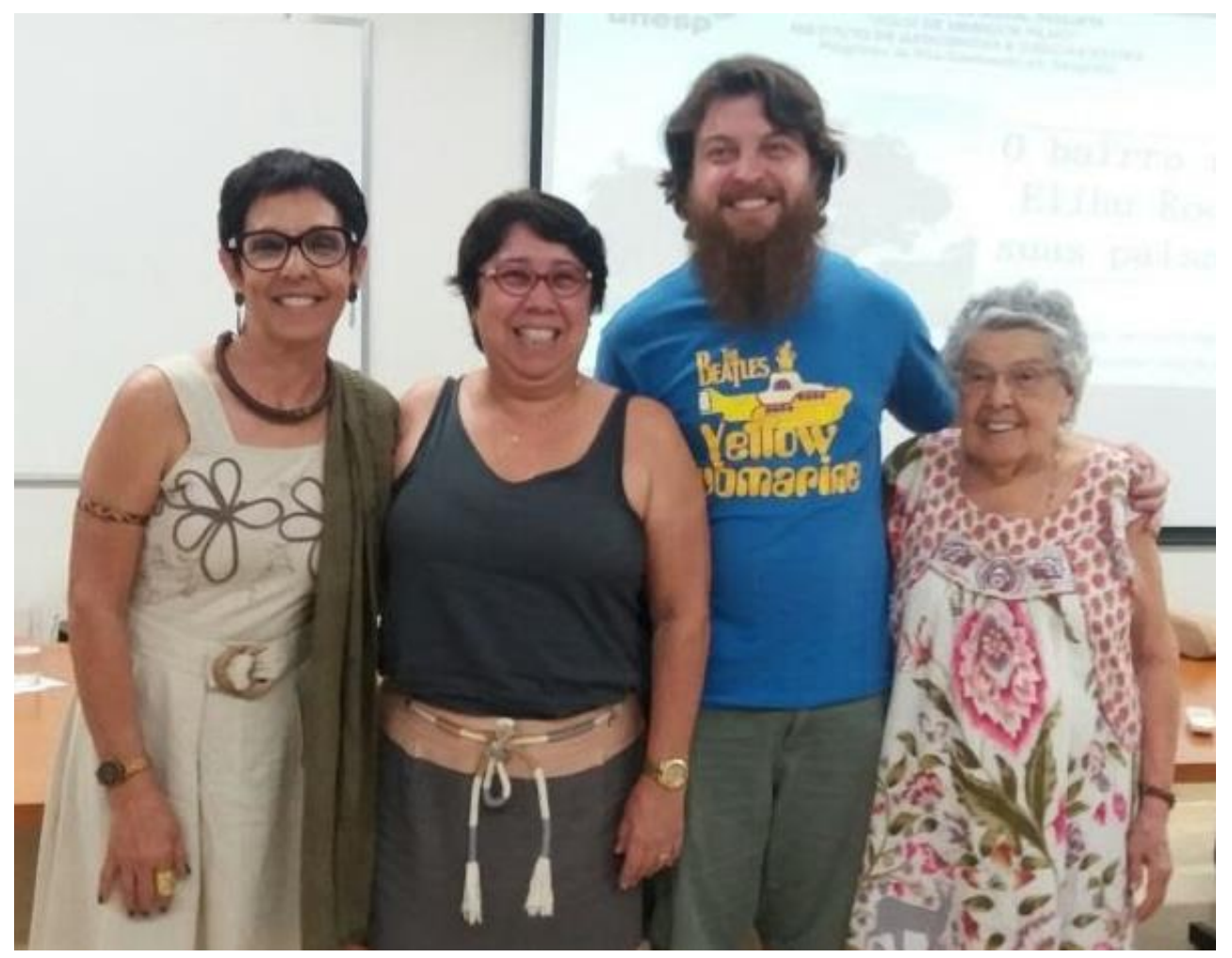

Fonte: Acervo pessoal.

Ao ingressar no mestrado, residia e lecionava em Campinas. Então professor na Rede Estadual de São Paulo, minhas idas à Rio Claro se resumiam

${ }^{1}$ Doutorando pelo Programa de Pós-Graduação em Geografia da UFPR - bolsista CAPES. Mestre em Geografia pela UNESP - Rio Claro. E-mail: hmarandola@yahoo.com.br 
às disciplinas e orientações. Com aulas todos os dias em Campinas, não pude desfrutar do convívio universitário e da famosa coleção de periódicos da biblioteca da Unesp. Rio Claro foi para mim, aulas na Unesp e conversas na casa de Lívia.

Sim, Lívia recebia seus orientandos em sua casa. Ao chegar em seu apartamento, costumava ser direta, sem muitos rodeios. Invariavelmente, havia enviado algum texto para sua apreciação prévia (sempre impressos e entregues com a gentileza de Tiago, também orientando de Lívia até 2016, ou Marcelo, sobrinho de Lívia). Enviava os textos a ela e ficava aguardando sua ligação. Assim que ela terminava de ler, me telefonava e agendava a orientação.

Sua leitura era minuciosa. Questionava a utilização dos conceitos, a apropriação de ideias dos autores, os sentidos de determinadas frases... Lívia me guiou na escrita. Sentado ao lado de sua mesa de madeira maciça, com um espaço para que pudesse fazer minhas anotações, Lívia traçava como que um mapa, ditando as coordenadas que eu deveria seguir para chegar aos objetivos que havia proposto. Quando me perdia, ela me puxava de volta pela mão.

Ao finalizar as orientações, deixávamos o escritório e seguíamos para a cozinha. Finalizado o trabalho, o tom da conversa agora era outro. Lívia preparava um café, oferecia uma quitanda ou quitute e conversávamos. Me questionava sobre o trabalho, a namorada (que se tornou esposa durante o mestrado), a nova cidade (mudei para Curitiba ainda no mestrado), a família... $\mathrm{Eu}$, por minha vez, lhe perguntava sobre suas viagens, pesquisas, eventos, orientandos, carreira, família...

Lívia foi uma orientadora rigorosa. Rigor científico, rigor na escrita, rigor na forma de apresentar os resultados. Se dedicava e se debruçava na pesquisa com seus orientandos. Assim o fazia pois dizia que por levar seu nome como orientadora, a pesquisa também era sua responsabilidade.

Seu amor pela vida, pelo conhecimento, pela geografia, transbordava em seus textos, palestras e conversas. Encerro essas poucas palavras com uma singela homenagem que escrevi na ocasião de seu falecimento (MARANDOLA, 2020): 


\section{Homenagem à professora Lívia de Oliveira}

"Quando o deus Olofi criou as outras divindades, deu a cada uma um lápis com uma borracha na ponta, para escrever de um lado e apagar do outro. O lápis que ele deu a Oxum estava incompleto. O que ela escreve não se pode apagar. [...] O que ela faz não é possível esquecer. Nunca se pode esquecer. O que ela faz, faz para sempre."

Eduardo Galeano, 2018, p. 87.

"Leitora voraz! Ávida pelo conhecimento! Amante da Geografia! Mestra de tantas e tantos. Presidiu sua última banca de defesa de mestrado aos 90 anos. Com paciência, rigor e carinho me guiou pelos trilhos da Geografia. Assim como a tantos outros antes de mim!

O que escreveu com sua caneta precisa, detalhista, rigorosa e poética jamais será apagado. Sua obra reverbera nos leitores e nos inúmeros pesquisadores que ajudou a formar.

Adeus Lívia, estará conosco pra sempre!"

\section{REFERÊNCIAS}

GALEANO, Eduardo. Conto um conto de Babalu. In: GALEANO, Eduardo. Vagamundo. Porto Alegre: L\&PM POCKET, 2018. p. 78-88.

MARANDOLA, Hugo Leonardo. Maracas-matrizes na paisagem do bairro rural Elihu Root: um trilhar humanista. Dissertação (Mestrado em Geografia) Instituto de Geociências e Ciências Exatas, Universidade Estadual Paulista "Júlio de Mesquita Filho", Rio Claro, 2017.

MARANDOLA, Hugo Leonardo. Homenagem à Professora Lívia de Oliveira. NEER, 7 de junho de 2020. Disponível em: http://neer.com.br/homenagem-aprofessora-livia-de-oliveira/. Acesso em: 3 de agosto de 2020. 